Werner Holly

Politikersprache 



\section{Werner Holly}

\section{Politikersprache}

Inszenierungen und Rollenkonflikte im informellen Sprachhandeln eines Bundestagsabgeordneten

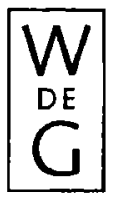

Walter de Gruyter - Berlin - New York 1990 


\section{Holly, Werner:}

Politikersprache : Inszenierungen und Rollenkonflikte im informellen Sprachhandeln eines Bundestagsabgeordneten / Werner Holly. - Berlin ; New York : de Gruyter, 1990

Zugl.: Trier, Univ., Habil.-Schr., 1988

ISBN 3-11-012307-X

(C) Copyright 1990 by Walter de Gruyter \& Co., D-1000 Berlin 30

Dieses Werk einschließlich aller seiner Teile ist urheberrechtlich geschützt. Jede Verwertung außerhalb der engen Grenzen des Urheberrechtsgesetzes ist ohne Zustimmung des Verlages unzulässig und strafbar. Das gilt insbesondere für Vervielfältigungen, Ubersetzungen, Mikroverfilmungen und die Einspeicherung und Verarbeitung in elektronischen Systemen.

Printed in Germany

Satz und Druck: A. Collignon, Berlin 30

Buchbinderische Verarbeitung: Lüderitz \& Bauer, Berlin 61 